\title{
SOD ACTIVITY IN CAM PLANT KALANCHOE DAIGREMONTIANA EXPOSED TO $\mathrm{SO}_{2}$
}

\author{
ZBIGNIEW MISZALSKI \\ Polish Academy of Sciences \\ The Franciszek Górski \\ Department of Plant Physiology, 31-016 Cracow, \\ ul. Sławkowska 17, Poland
}

(Received: March 10, 1995. Accepted: July 10, 1995)

\begin{abstract}
The Kalanchoe daigremontiana CAM plants exhibit very low sensitivity to the action of sulphite dioxide. Fumigation for a week with $3 \mathrm{ppm} \mathrm{SO}_{2}$ leads to an increase in the dismutation rate of the oxygen radical expressed in units of SOD activity and an increase in SOD activity itself. This strong increase disappears $100 \mathrm{~h}$ after fumigation. A transient increase in SOD activity represents an adaptation mechanism to oxidative stress caused by $\mathrm{SO}_{2}$.
\end{abstract}

KEY WORDS: CAM, Kalanchoe daigremontiana, $\mathrm{SO}_{2}$, $\mathrm{SOD}$.

\section{INTRODUCTION}

CAM plants are in general less sensitive to the action of atmospheric $\mathrm{SO}_{2}$ than those of the $\mathrm{C}_{3}$ or $\mathrm{C}_{4}$ type (Nyman et al. 1990, Olszyk et al. 1987). Because the CAM plants have their stomata open during the night it may be expected that a considerable amount of sulphur dioxide will penetrate to the inside of the leaves precisely during the period of darkness. During the day these plants should be injured by this gas to a lesser extent since less sulphur will penetrate to the mesophyll cells and, moreover, the detoxification process of sulphur dioxide proceeds with great intensity with light (Miszalski and Niewiadomska 1992, Rothermel and Alscher 1985). Contrary to the above assumptions are the results published by Olszyk et al. (1987) reporting greater sensitivity of the CAM plants to the action of $\mathrm{SO}_{2}$ when illuminated. This can be explained be the development of toxic sulphite radicals (Asada 1980, Beauregard 1991).

Since the ability to dismutate $\mathrm{O}_{2}-$ and the activity of SOD are factors usually correlating with sensitivity to $\mathrm{SO}_{2}$ and the rate of its detoxification (Niewiadomska et al. 1995, Tanaka and Sugahara 1980), the aim of the present investigations was to carry out measurements of these parameters on a CAM plant fumigated with sulphur dioxide. Considering the essential role of light in the process of $\mathrm{SO}_{2}$ interaction with the plants, the experiments were carried out on illuminated and on shaded leaves.

\footnotetext{
Abbreviations:

CAM - Crassulacean Acid Metabolism,

SOD - Superoxide dismutase [EC. 1.15.1.1.]
}

\section{MATERIAL AND METHODS}

\section{Material and fumigation}

Kalanchoe daigremontiana (Hamet et Perrier) plants growing on a substrate of soil and sand (1:1) were propagated and raised before the experiment for at least two months in light with an intensity of $150 \mu \mathrm{mol} \mathrm{s}-1 \mathrm{~m}^{-2}$ at plant height. The temperature was kept at $28 / 19 \pm 2^{\circ} \mathrm{C}$ (day/night, $12 / 12 \mathrm{~h}$ ), while the relative humidity was about $35-55 \%$.

The plants were exposed in plexiglass chambers for $12 \mathrm{~h}$ during the day to the action of $3.0 \pm 0.1 \mathrm{ppm} \mathrm{SO}_{2}$ (air change 2.5 volumes/min) for 1 week at a temperature of $25 / 20^{\circ} \mathrm{C}$, illumination of $100 \mu \mathrm{mol} \mathrm{s}^{-1} \mathrm{~m}^{-2}$, and relative humidity of about $70 \%$ (Langebartels et al. 1991). $\mathrm{SO}_{2}$ from a pressure cylinder was added to conditioned air by mass flow controllers. The concentration of this gas was measured every hour with Sulfur Gas Analyzer (Meloy USA). $\mathrm{SO}_{2}$ free air was applied to control plants during the whole experimental period. For fumigated plants $\mathrm{SO}_{2}$ free air was applied during night time and next also for 10 or $100 \mathrm{~h}$ after 1 week fumigation. From each pair of leaves one leaf was protected against light (shaded leaf) with aluminium foil while enabling the access of air. For each experiment the 3rd or 4th pair of leaves from the top of the plant were collected. Leaf discs were excised for analysis 10 or $100 \mathrm{~h}$ after fumigation.

\section{SOD activity.}

The leaf material was frozen and then analyzed after homogenization in the $10 \mathrm{ml} 0.2 \mathrm{M}$ phosphate buffer $\mathrm{pH} 7.8$ containing $1 \mathrm{mM}$ EDTA. The ability of $400 \mu \mathrm{l}$ of such homogenate to removing $\mathrm{O}_{2}$ was measured exactly as in the method for SOD determination (Elstner and Heupel 1976) but 
without dialysing the homogenate. SOD was determined after $20 \mathrm{~h}$ dialysation of the homogenate against $110.2 \mathrm{M}$ phosphate buffer $\mathrm{pH}$ 7.8. Then the homogenate was tested in medium containing $0.05 \mathrm{U} \mathrm{ml}^{-1}$ xanthine oxidase, $0.375 \mathrm{mM}$ xanthine, $0.5 \mathrm{mM}$ hydroxylamine. Reaction was started with xanthine and stopped after $30 \mathrm{~min}$ with $30 \mathrm{mM}$ sulfanilamid acid. SOD activity was determined after measuring the $\mathrm{O}_{2}$ level by comparison with the standard curve made with SOD ordered by Sigma. $\mathrm{O}_{2}$ was measured at $540 \mathrm{~nm}$ after addition of N-1-naphtylethylendiamine to the concentration of $25 \mathrm{mM}$. Chlorophyll concentration was measured according to Arnon (1949).

Statistical analysis was done using Mann-Whitney test.

\section{RESULTS}

The results shown in Fig. 1 indicate that the dismutation rate of the oxygen radical expressed in units of SOD activity amounted to 77 and $81 \mathrm{U} \mathrm{mg}^{-1} \mathrm{chl}$ for homogenates from shaded and illuminated control leaves, repectively. Fumigation for a week with 3 ppm $\mathrm{SO}_{2}$ led to an increase in these parameters to the values of 105 and $141 \mathrm{U}$ (SOD) $\mathrm{mg}^{-1} \mathrm{chl}$, respectively, in experiment in which the measurement was made 10 $\mathrm{h}$ after fumigation. The values of these parameters $100 \mathrm{~h}$ after fumigation were reduced to 94 and $84 \mathrm{U}$ (SOD) $\mathrm{mg}^{-1} \mathrm{chl}$ for homogenates from shaded and illuminated leaves, respectively.

In experiments of similar arrangement, in which the activity of SOD was measured, was demonstrated (Fig. 2) that the activity of this enzyme it was 30 and $33 \mathrm{U}$ (SOD) $\mathrm{mg}^{-1} \mathrm{chl}$ for homogenates from shaded and illuminated leaves, respectively, while after fumigation these values increased to 50 and 60 $\mathrm{U} \mathrm{mg}^{-1} \mathrm{chl}$, respectively, in experiments carried out $10 \mathrm{~h}$ after fumigation. The values of these parameters $100 \mathrm{~h}$ after fumigation had fallen to 25 and $39 \mathrm{U} \mathrm{mg}^{-1} \mathrm{chl}$ for homogenates from shaded and illuminated leaves, respectively.

\section{DISCUSSION}

The Kalanchoe daigremontiana plants exhibit very low sensitivity to the action of sulphur dioxide. As indicated by the results of a number of studies (Fujinuma and Aiga 1980, Katainen et al. 1987, Steubing and Fangmeier 1987, Totsuga 1980), even several hours long exposure of the $C_{3}$ plants to the action of $\mathrm{SO}_{2}$ concentrations lower than $3 \mathrm{ppm}$ (as used in the present experiments) leads to the occurence of extensive necrosis, dying away of the tissue, and deep changes in the metabolism. Even in highly polluted regions the average concentration reaches $0.1 \mathrm{ppm} \mathrm{SO}_{2}$. Concentrations in the range of 0.035-0.750 are often used for evaluating $\mathrm{SO}_{2}$ effects on plants (Darrall 1989). In present experiments we have observed no necrosis after 1 week fumigation with $3 \mathrm{ppm} \mathrm{SO}_{2}$.

The activity of SOD in the leaves of Kalanchoe daigremontiana is comparable to the activity measured in other plants, e.g., pine needles or poplar leaves (Polle et al. 1990, Tanaka and Sugahara 1980), which suggests that the activity of this enzyme cannot account for the low sensitivity of these plants to $\mathrm{SO}_{2}$. The ability of a plant to dismutate the oxygen radical increases as a consequence of fumigation with $\mathrm{SO}_{2}$, similarly as in the experiments on poplar and spinach leaves carried out by Tanaka and Sugahara (1980). This ability increases in both shaded and illuminated leaves. A stronger increase of this parameter in the present experiments with the homogenates from illuminated leaves is an indication that free radicals develop in great amounts in the course of fumigation during illumination. This is also an indication that a $12 \mathrm{~h}$ night period (over the week) was not long enough for the leaves to recover after $12 \mathrm{~h}$ fumigation. A considerably stronger increase in the ability to dismutate the oxygen radical, not directly connected with the activity of SOD, suggests that the activated defense mechanisms in these plants are not restricted to the SOD synthesis but include also other systems used for the dismutation of free radical substances, e.g. glutathion or ascorbic acid. These defense mechanisms will probably be stronger during

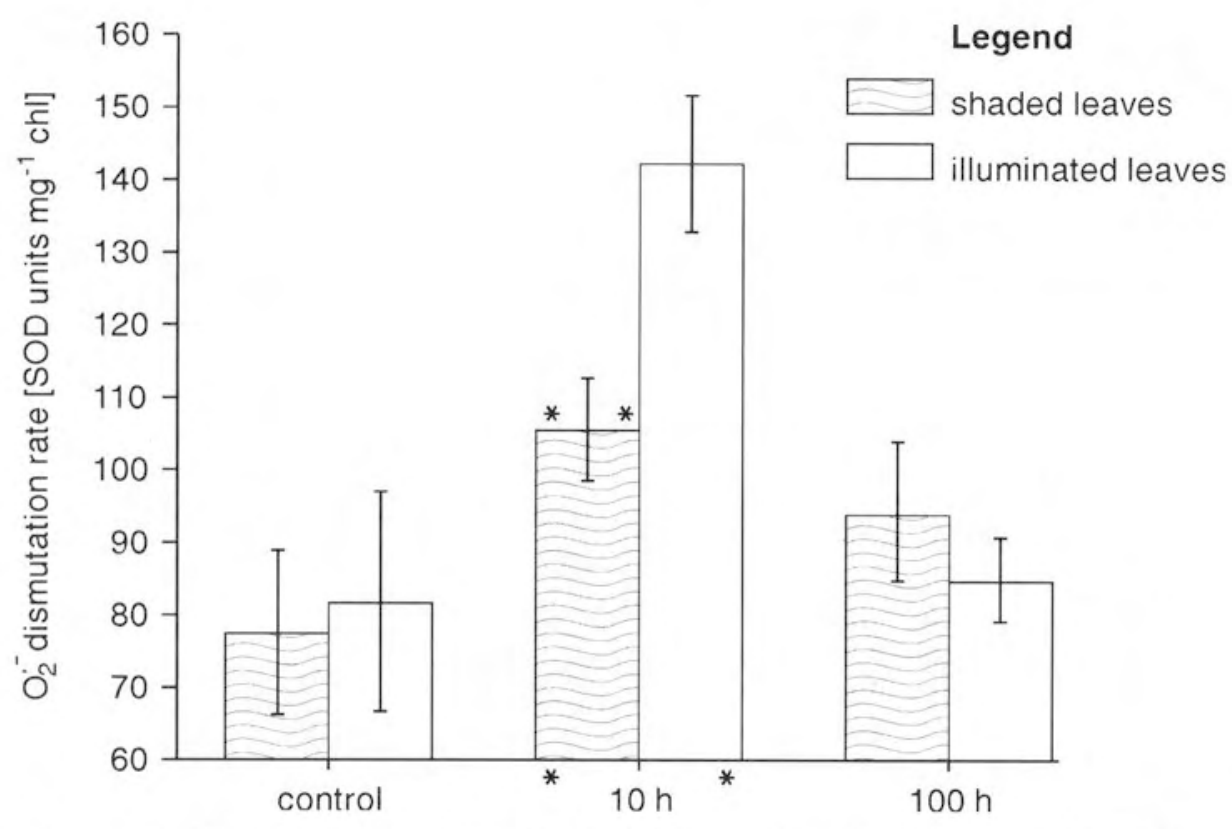

Fig. 1. Dismutation rate of oxygen radical in homogenates of shaded or illuminated Kalanchoe daigremontiana leaves fumigated for 1 week with $3 \mathrm{ppm} \mathrm{SO}_{2}$. Values, expressed in units of SOD, were measured 10 or $100 \mathrm{~h}$ after fumigation. Vertical bars indicate SD of the calculated means. Signs * - show the relative significance from the control, sign ** - show the relative significance from the illuminated sample, where $\mathrm{p}<0.05$. 


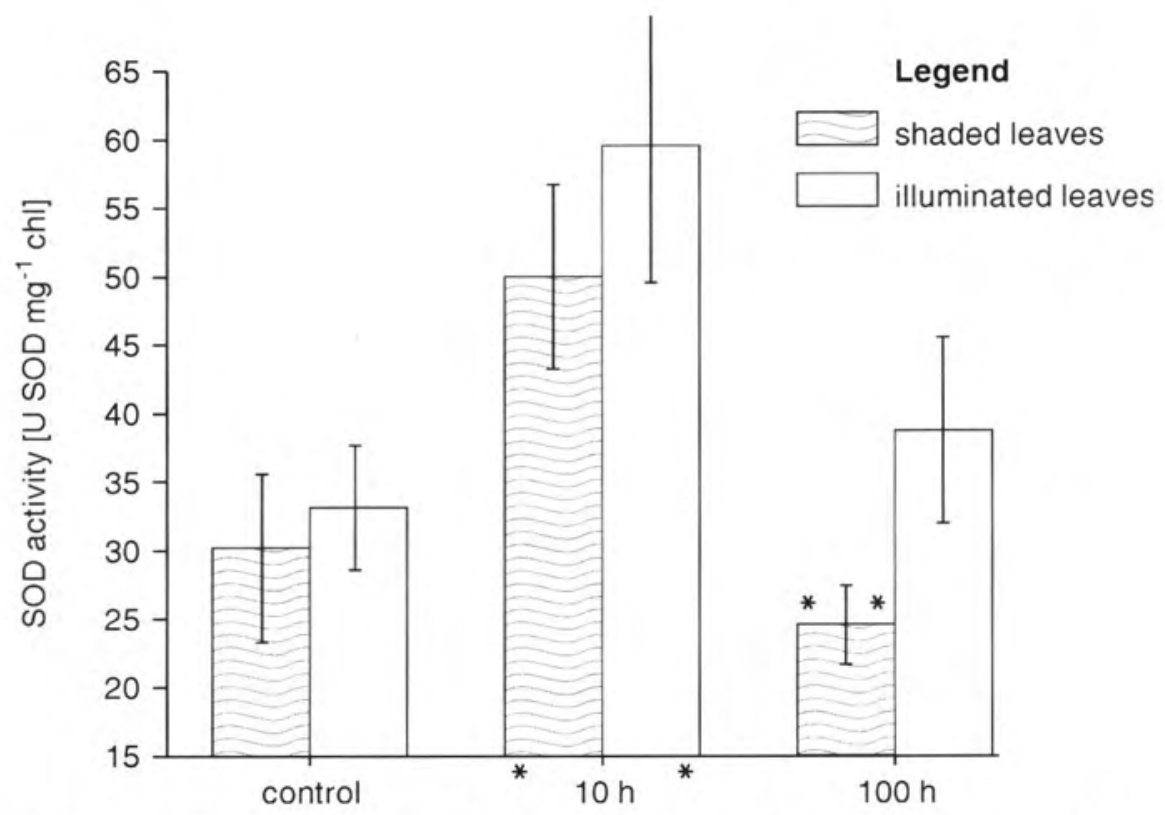

Fig. 2. SOD activity measured 10 or $100 \mathrm{~h}$ after fumigation in homogenates of shaded or illuminated Kalanchoe daigremontiana leaves fumigated for 1 week with $3 \mathrm{ppm} \mathrm{SO}$. Vertical bars indicate SD of the calculated means. Signs * - show the relative significance from the control, sign $* *$ - show the relative significance from the illuminated sample, where $p<0.05$.

fumigation in light. The increase in the activity of SOD as well as the capacity for dismutation of the oxygen radical is relatively stable and is maintained on a fairly high level for 10 $\mathrm{h}$ after fumigation. $100 \mathrm{~h}$ after fumigation these values have fallen considerably.

On the basis of the obtained results, however, it is not possible to establish that the toxicity of $\mathrm{SO}_{2}$ is strongly dependent on the light conditions. Although many literature data point to the fact of stronger detoxification of $\mathrm{SO}_{2}$ in light, we did not observe any protective function of light in our experiments. On the contrary, a stronger increase in the SOD level and in the capacity for dismutation of the oxygen radicals in light may be interpreted as indicating increased toxic interaction of sulphur dioxide precisely in the illuminated leaves. This might be connected with the development of toxic sulphite radicals. These differences were observed despite of the $12 \mathrm{~h}$ night period without fumigation. In view of the fact that the CAM plants often grow under conditions of strong illumination, this process may be of great importance for them. The final effect of $\mathrm{SO}_{2}$ will be determined by the rate of its detoxification and the intensity of the interaction of free radicals. In spite of the increased toxicity of $\mathrm{SO}_{2}$ in light they exhibit considerable resistance. According to Kaiser et al. (1989), $\mathrm{SO}_{2}$ may undergo detoxification in the cells through its transport to the vacuoles. As the vacuole in the cells of the CAM type are greatly developed it may be anticipated that such a mechanism may also function in these plants.

\section{ACKNOWLEDGMENTS}

The author is indebted to Prof. H. Sandermann and Dr. C. Langebartels for the opportunity of causing out fumigation of plants in GSF in Munich. I thank Prof. H. Ziegler for suggesting the experimental approch. This work has been supported by The Polish Committee for Scientific Research (KBN) No. 6 P205 01604.

\section{LITERATURE CITED}

ARNON D.J., 1949. Copper enzymes in isolated chloroplasts. Phenoloxidase in Beta vulgaris. Plant Physiol. 24: 1-15.

ASADA K., 1980. Formation and scavenging of superoxide in chloroplasts, with relation to injury by sulfur dioxide. Res. Rep. Natl. Inst. Environm. Stud. 11: 165-181.

BEAUREGARD M., 1991. Involvement of sulfite and sulfate anions in the $\mathrm{SO}_{2}$-induced inhibition of the oxygen evolving enzyme photosystem II in chloroplasts: A reviev. Env. Exp. Bot. 31: 11-21.

DARRALL N.M., 1989. The effect of air pollutants on physiological processes in plants. Plant Cell Environ. 12: 1-30.

ELSTNER E.F., HEUPEL A., 1976. Inhibition of nitrate formation from hydrolamonium chloride. A simple assay for superoxide dismutase. Annal. Biochem. 70: 616-620.

FUJINUMA Y., AIGA I., 1980. Selected rice (Oryza sativa L.) strains as an indicator plant for air pollution. Res. Rep. Natl. Inst. Environm. Stud. 11: 255-263.

KAISER G., MARTINOIA E., SCHRÖPPEL-MEIER G., HEBER U., 1989. Active transport of sulfate into the vacuole of plant cells provides halotolerance and can detoxify $\mathrm{SO}_{2}$. J. Plant Physiol. 133: 756-763.

KATAINEN H-S., MÄKINEN E., JOKINEN J., KARJALAINEN R., KELLOMÄKI S., 1987. Effects of $\mathrm{SO}_{2}$ on the photosynthetic and respiration rates in scots pine seedlings. Env. Poll. 46: 241-251.

LANGEBARTELS C., KERNER K., LEONARDI S., SCHRAUDNER M., TROST M., HELLER W., SANDERMANN H. 1991. Biochemical plant responses to ozone. Plant Physiol. 95: 882-889.

MISZALSKI Z., NIEWIADOMSKA E., 1992. $\mathrm{SO}_{2}$ oxidation during greening of Avena sativa seedlings. Photosynthetica 28:577-581.

NIEWIADOMSKA E., MISZALSKI Z., MORAŃDA J., 1995. Nonuniform sensitivity to $\mathrm{SO}_{2}$ within one variegated leaf of Chlorophytum comosum. Phyton 35 (Austria) (in press).

NYMAN L.P., BENZING D.H., TEMPLE P.J., ARDITTI J., 1990. Effects of ozone and sulfur dioxide on two epiphytic orchidis. Env. Exp. Bot. 30: 207-213.

OLSZYK D.M., BYTNEROWICZ A., FOX C.A., 1987. Sulfur dioxide effects on plants exibiting Crassulacean acid metabolism. Env. Poll. 43: 47-62. 
POLLE A., CHAKRABARTI K., SCHÜRMANN W., RENNENBERG H., 1990. Composition and properties of hydrogen peroxide decomposing systems in extracellular and total extracts from needles of Norway spruce (Picea abies L. Karst). Plant Physiol. 94: 312-319.

ROTHERMEL B., ALSCHER R., 1985. A light-enhanced metabolism of sulfite in cells of Cucumis sativus L. cotyledons. Planta 166: 105-110.

STEUBING L., FANGMEIER A., 1987. $\mathrm{SO}_{2}$-sensitivity of plant communities in a beech forest. Env. Poll. 44: 297-306.
TANAKA K., SUGAHARA K., 1980. Role of superoxide dismutase in defense against $\mathrm{SO}_{2}$ toxicity and an increase in superoxide dismutase activity with $\mathrm{SO}_{2}$ fumigation. Plant Cell Physiol. 21: 601611.

TOTSUGA T., 1980. A model for estimating $\mathrm{SO}_{2}$ effects on conopy photosynthesis in sunflower plants. Res. Rep. Natl. Inst. Environm. Stud. 11: 19-30.

\section{AKTYWNOŚĆ SOD W LIŚCIACH ROŚLINY TYPU CAM KALANCHOE DAIGREMONTIANA EKSPONOWANYCH NA DZIAŁANIE $\mathrm{SO}_{2}$}

\section{STRESZCZENIE}

Przedstawiciel roślin charakteryzujących się metabolizmem typu CAM - Kalanchoe daigremontiana wykazuje niską wrażliwość na działanie dwutlenku siarki. Ekspozycja roślin przez okres 1-tygodnia w atmosferze zawierającej $3 \mathrm{ppm} \mathrm{SO} 2$ manifestuje się we wzroście zdolności dysmutacji anionorodnika ponadtlenkowego wyrażanej w jednostkach aktywności SOD jak i wzroście aktywności samej SOD. Obserwowane zmiany ulegają cofnięciu w $100 \mathrm{~h}$ po zakończeniu ekspozycji na działanie $\mathrm{SO}_{2}$. Przejściowy wzrost aktywności SOD stanowi mechanizm adaptacyjny w warunkach stresu oksydacyjnego wywoływanego $\mathrm{SO}_{2}$.

SŁOWA KLUCZOWE: CAM, Kalanchoe daigremontiana, $\mathrm{SO}_{2}$, $\mathrm{SOD}$. 